\title{
ACCESSIBILITY OF INTERNATIONAL WEBPAGES:A PRELIMINARY SURVEY
}

Nachiketa Rout* ${ }^{1}$, Reegan Amarnath ${ }^{2}$, Neeradha Chandramohan ${ }^{3}$

*1,2 Department of Speech Hearing and Communication, National Institute for Empowerment of Persons with Multiple Disabilities, Tamil Nadu, INDIA

${ }^{3}$ The Director, National Institute for Empowerment of Persons with Multiple Disabilities, Tamil Nadu, INDIA

*Correspondence Author: nachiketa_raut@yahoo.com

\begin{abstract}
:
The paper surveys the extent to which the international webpage's applied accessibility statements. Methodology includes thirty one international websites have been evaluated for 17 accessibility features prescribed in the accessibility statement by the Directorate of Standardization testing and quality certification (STQC) along with five accessibility features prescribed byWeb content accessibility guidelines (WCAG).The average score obtained was seven. Top scorers were the Ministry of Road and Transport (21), National institute for Empowerment of Person with Multiple Disabilities (16) and Yahoo webpage (12) Bottom scorers were Wikipedia (7), American Speech and Hearing Association (8), Meccawebpage (8) Massachusetts university (6) and International telecommunication union, toolkit for Disables (6).The features which are significantly applied $(p<0.05)$ are Headings, Subheadings, Titles, Tooltip, Connection with social networking and Videos. The feature which were not significantly used by the websites are Skip to main content, icons, Accessibility features, Adjust contrast scheme and Increase text spacing other Twelve features were used in consistently. Hence the accessibility statements which enable merging the digital divide are yet to be appreciated internationally.
\end{abstract}

Keywords:

International Websites, Accessibility Statement, STQC, Disabilities, WCAG.

\section{INTRODUCTION:}

The mouse has divided the world in to two, a group which can access the world through the internet and other which cannot. This is referred to as digital divide and is of major concern (DiMaggio et al. 2004; Hargittai 2003; Lenhart et al. 2003; Norris 2001; van Dijk 2005; Warschauer 2003).Therecent generation, born between 1980 to 1990 caused the divide at home, in public places and at home. Asthey grew up with the development of computers, referred to as "generation Y"(Generation Y, 2013). The generation Y could use the latest machines and access the web with an unprecedented efficiency as compared to the earlier generations and have become an issue of concern. Tobridge the gap the machines need to be made "easy to use" or accessible. Lack of accessibility of information from the web impedes work for many.

Effective dissemination and accessibility of information by one and all is one of the major goal which every government and governance is targeting hard to achieve. It's further important as, 


\section{INTERNATIONAL JOURNAL Of RESEARCH -GRANTHAALAYAH \\ A knowledge Repository}

Art

accessibility to information is a humanrightissue. It has picked up momentum internationally and in India after the implementation of the Right To information Act passed by the government of India in year 2005(Right to Information, 2005). This challenge of receiving and disseminatinginformation seemed to have had a solution with the emergence of the facility to post information through the internet. However the solution came up with a new challenge referred to as "digital divide".To understand the digital divide and how it affects participation of a person in his society, the International classification of health (ICF) classification prescribed by the WHO in 2001is of help. The ICF, 2001 tries elaborating upon how anindividual's capability to be an active and contributing member of a society is impeded by various environmentalfactors and personal

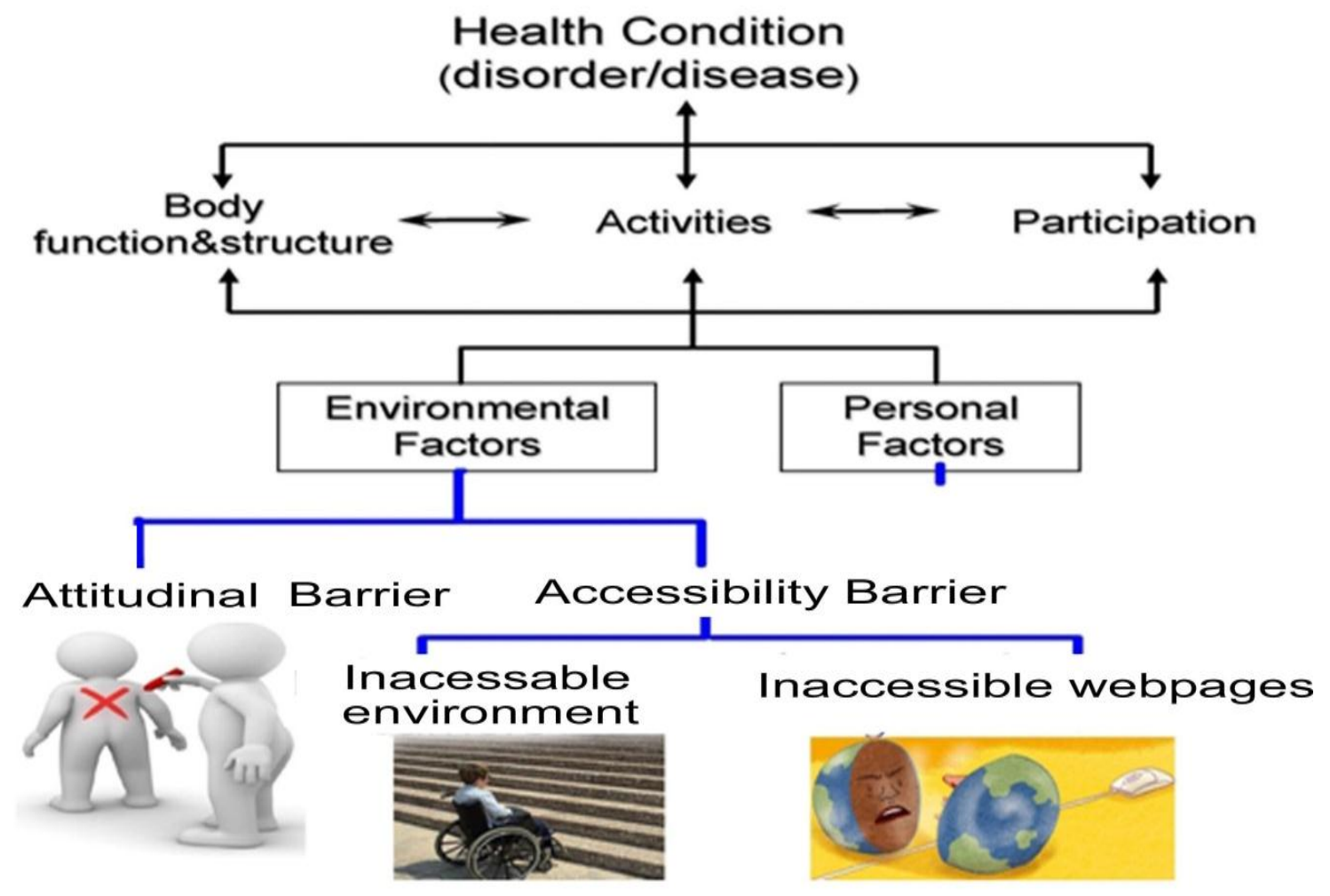

Figure 1: Interaction between the various components of ICF (WHO, 2001) and elaboration of the environmental factors which impede person s participation.

The ICF provides appropriate instrument for the implementation of stated international human rights mandates as well as national legislations (WHO, 2001). ICF is a classification of health and health-related domains which includes disabilities/ persons with disabilities. These domains are classified from body, individual and societal perspectives by means of two lists: a list of body 


\section{INTERNATIONAL JOURNAL Of RESEARCH -GRANTHAALAYAH

functions and structure, and a list of domains of activity and participation. Since an individual's functioning and disability occurs in a context, the ICF also includes a list of environmental factors .The environmental factors and their influence on the social participation of the person. Environmental factors can be further classified as attitudinal barriers i.e. negative attitudes of the people in the society who feel that a person with disability "cannot" do things and architectural barriers which includes structural barriers and in accessible information from print and electronic media including the web pages (Fig 1).

In India, the charm of government jobs faded and the economic divide within the middle class increased with the emergence of the highly paying software industry which offered high salary package and air conditioner work set up. The nature of work in the software industry unlike the previous sector was in and around computers. The success in terms of using computers and the web governed in the software industry achieve vocational success. The proficiency with which the "generation Y" uses the computers and web sites gives them a clear cut edge above the other generation. The only solution is to merge the divide is to make the web accessible for the earlier generation. This paper aims to discover ways in which the web can be made accessible to one and all universally.

Accessibility is the degree to which a product, device, service, or environment is available to as many people as possible. Accessibility is not to be confused with usability, which is the extent to which a product (such as a device, service, or environment) can be used by specified users to achieve specified goals with effectiveness, efficiency and satisfaction in a specified context of use.Accessibility can be viewed as the "ability to access" and benefit from some system or entity. The concept is needed for one and all universally but often focuses on people with disabilities or special needs and their right of access, enabling the use of technology.

Accessibility is of universal concern it needs to be understood and implemented in a broader way. The universal design on web was proposed internationally first by UNESCO, WHO followed by the University of Washington in USA (University of Washington, 2001). Since then several organisations have been working on promoting accessibility on web. The leading organisations include Standardization Testing and Quality Certification (STQC)in India under the Ministry of Communication Information Technologyin India since, 1980 and the University of Washington. The web content accessibility guidelines (WCAG, 2008), The World Wide Web Consortium (W3C) develops and maintains the protocols to promote universal access. Tim Berners-Lee, Director of the W3C believes: The power of the web is in its universality. Access by everyone regardless of disability is an essential aspect." (WCAG, 2008) The aim of the study is to evaluatethe extent to which the international webpage's applied accessibility statements as prescribed by the STQC and WCAG.

\section{METHODOLOGY}

Thirty oneInternational websites were selected based uponon purposive sampling with the perspectives of PublicHealth, Social responsibility, Wealth, Education, Spirituality, Popularity, 


\section{INTERNATIONAL JOURNAL Of RESEARCH -GRANTHAALAYAH \\ A knowledge Repository}

Art

Defence,populationand Institutes working for the persons with disabilities(Appendix, A).The 17 STQC accessibility features (accessibility statement, 2008) and additional five accessibility features from WCAG (2008) were adapted to rate the accessibility of the international websites.

\subsection{TOOL}

The study was conducted by adopting the STQC Accessibility (seventeen accessibility features) along with WCAG guidelines (Five accessibility features) the same which were recommended by the authors to develop a checklist. The STQC awarded websites were reviewed to appreciate the parameters(Appendix, B)The Twenty-two itemed checklist having 17 STQC and WCAG guidelines were used to measure the accessibility features applied on the web. The mentioned webpages were rated using the developed tool. The presence of the accessibility features on the web page was marked byone (1) and the absence of it was rated as zero (0). The STQC awarded websites were reviewed to ensure the parameters.

\subsection{PROCEDURE}

The web was searched for the accessibility feature guidelines and organisation involved in formulating or implementing it. A review of the STQC accessibility statement was done along with a review of few internationally prescribed guidelines from WCAG. The details of the guidelines were appreciated by reviewing three websites (AYJNIHH, NIEPMD, National Security Depository limited, Central depository (I) limited) which had received STQC awards through government of India since the year of 2010 by a National award for being accessible websites and had STQC certifications.Fewpopular international websites were reviewed to identify the way in which accessibility features are implemented on the webpages. The webpages are like Yahoo, Google, Wikipedia, Face book .Two research scholars and the Head of the department of computer applications from Dr. M.G.R educational research institute, Chennai were consulted about the definitions and applications of accessibility before finalizing the check list and the ratings.

A checklist was prepared (Appendix, B) and each webpage were evaluated for the presence and absence of the accessibility statement (features). The presence of the features was coded as 1 (one), while the absence of the feature coded as 0 (zero). The highest possiblescore is 22. A descriptive statistics and a Chi square test was done to Identify features which were significantly present or absent using SPSS version 16 software.

\section{RESULTS}

The application of the accessibility features by thirtyone InternationalWebpageswere surveyedand rated based upon the developed checklist (Appendix, B). The scores obtained by each website are depicted in figure 1. The maximum numbers of accessibility features were incorporated in Ministry of Road Transport India (21) followedby National Institute for Empowerment of Person with Multiple Disability (16) and Yahoo Webpage (12). The minimum 


\section{INTERNATIONAL JOURNAL Of RESEARCH -GRANTHAALAYAH \\ A knowledge Repository}

Art

accessibility features were incorporated in Wikipedia (7), American speech and hearing association (8) and Mecca website (8) andMassachusettsUniversity (6).An averageten accessibility features were impeded in those Webpages. Thirty internationalwebsites and the numbers of accessibility features put to use in them are depicted in the Fig. 2.

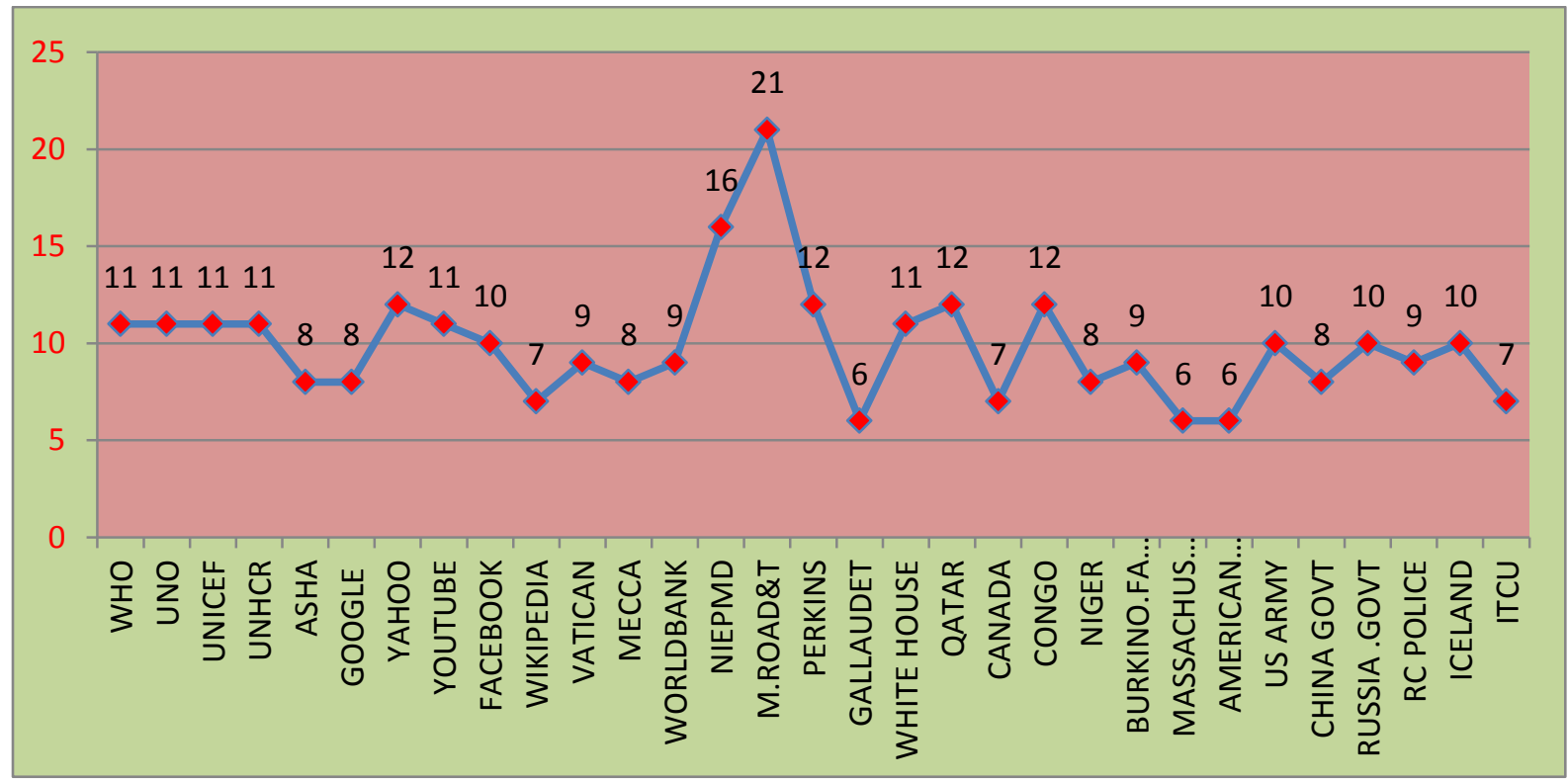

Figure 2: Thirty one International websites and the number of accessibility features put to use in them.

Figure: 2 Describe the Accessibility features incorporated in the above thirty international websites. The maximum number of Accessibility feature are maintained by the Ministry of Road transport India, following that National Institute for Empowerment of Persons with Multiple Disability, Yahoo webpage, UNO, UNICEF,UNHCR and the least features were incorporated in Wikipedia, American speech and hearing association ,Mecca and Massachusetts University.

A chi square was done to identify features which were used significantly or were neglected. The features significantly used features are Headings, Sub headings, Titles, connection with social networking, option to change the language, Tooltip option and Videos. The significantly not presented $(\mathrm{p}<0.05)$ features are iconic presentation, accessibility options like, changing the size of the text, changing the colour of the text, adjust contrast scheme, , identification of file type \& size, Increase text spacing and access of screen reader. Significantly presented features keyboard support, consistence navigation mechanism, Videos, screen saver option and tooltip. (Figure 3). 


\section{INTERNATIONAL JOURNAL Of RESEARCH -GRANTHAALAYAH \\ A knowledge Repository}

Art

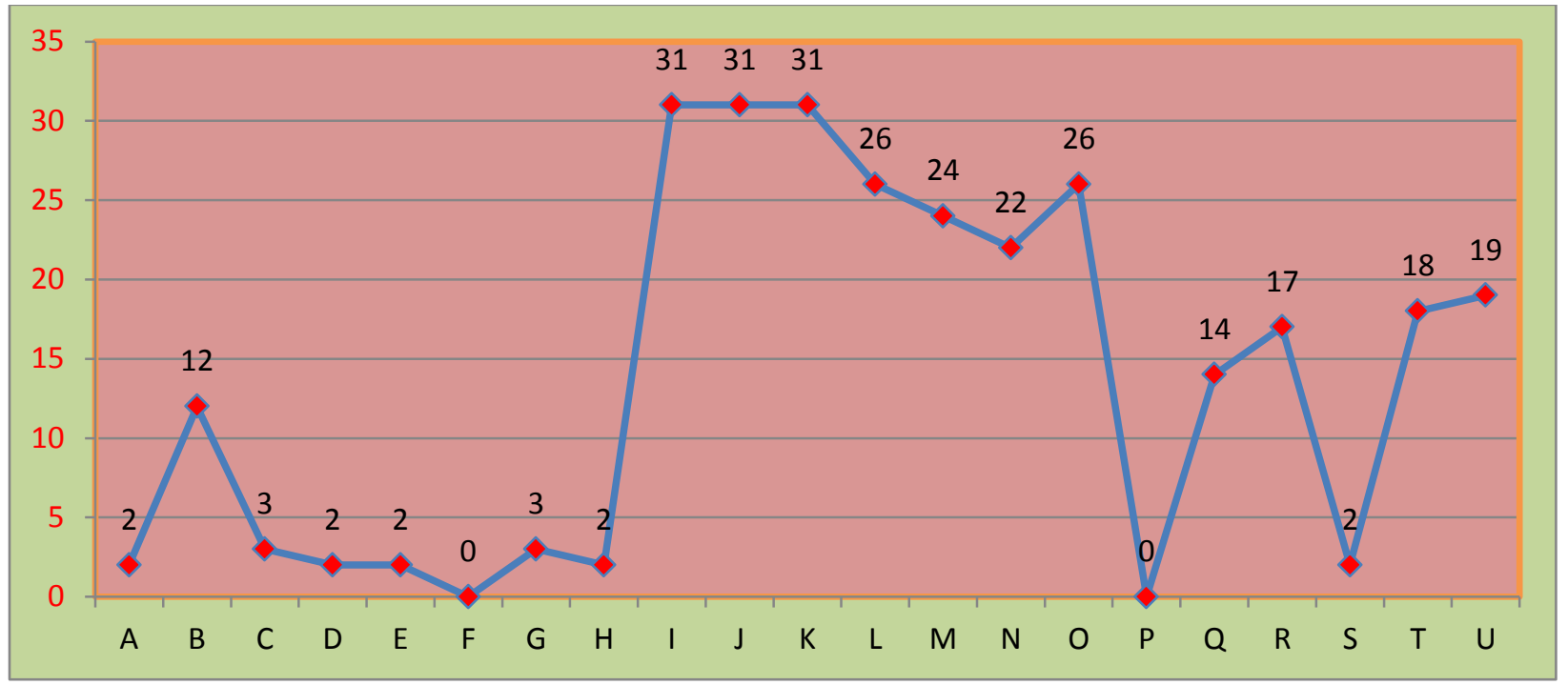

Figure 3: Indicates the Accessibility Options of WebPages been incorporated in the websites specifically. The figure shows the maximum possible score for the every 10 options of STQC features.A-Refers to skip to main content, B-Icons, C-Accessibility features, D-Change text size, E-Change colour of text, F-Increase text spacing, G-Identification of file type, H-Icons for different types of file I-, Heading, J-Sub heading, K-Title, L-Alternate text, M-Availability of tooltip, N-Consistent navigation mechanism, O-Keyboard support, P-Adjust contrast scheme , Q-Contents in own language, R-Screen saver option, S-Screen reader access, T-Visual screening(Videos), U-Connectivity with social networking's.

A to $\mathbf{P}$ - Accessibility features from STQC

Q to $\mathbf{U}$ - Accessibility features prescribed by WCAG guidelines.

\section{DISCUSSION}

The two top scores of the survey and had more than $60 \%$ of the features implemented and their Webpages were Ministry of road and Transport India and National Institute for Empowerment of Person with Multiple Disability. Both of the Webpages are government of India funded Webpages at the same none of the private funded webpages including the very popular webpage and search engines like Yahoo, Google, face book, YouTube UNO, UNICEF, UNHCR,ASHA and Wikipedia were implemented less than $60 \%$ of the accessibility features. This reflects an attitudinal barrier or ignorance on the Accessibility features and the need for them implement.

The majority of the international websites were yet not maintained many of the accessibility features that has been recommended by WCAG guidelines. There is no option for skip to main content or skip to navigation option facilities were available in any of the international website that has been reviewed except Ministry of Road and Transport of India and National Institute for 


\section{INTERNATIONAL JOURNAL Of RESEARCH -GRANTHAALAYAH

Empowerment of Person with Multiple disability (Figure 1). The only option that the international websites were maintained similarly is connection with social networking's it is not yet implemented strongly in some other national websites in India but the need is more and it is increased quite a bit now a days because of sharing the materials and some information through the social medias. The most important feature access of screen reader is not yet properly implemented by any of the international websites which considered ton the most accessible feature for the people with visual impairment.

Disability rights promotion international website, has given some short cut keys to use the accessibility feature that has been incorporated in their own website. The International websites somewhere like Google and yahoo Webpages were considered to be search engines they have given language options to open up any Webpages but there is no any other accessibility options were incorporated in this world wide famous search engine websites. Some websites like Vatican and Wikipedia were giving option to open up the website which the user wishes to open it. Most of the websites working for community development and developmental programs were also having the options to read the web content in their users own language but the languages are specific and approved by united nations as certified language. If the international website tries to follow up the WCAG guidelines or its well-developed version like W3C means it will be help the next generation of people especially to the people with disability. The where ever the videos also presented in some websites like United nations organization and united nations High commission for refugees, it was not strongly implemented in some other websites. For the most important the option to increase spacing between the words (Text spacing) option is not implemented in any of the international websites that has been surveyed.

The Recommendations of WCAG and some of the special option for Disabled people were not implemented in most any of the international websites, for example the recommendation of implementing the sign language videos in the websites were not implemented in any of the websites that we have reviewed.

Accessibility is strongly related to universal design when the approach involves "direct access." This is about making things accessible to all people (whether they have a disability or not). An alternative is to provide "indirect access" by having the entity support the use of a person's assistive technology to achieve access. For example, computer screen readers. (Wikipedia, 2013).There are two sides of the coin when it comes to helping people with disabilities get online: ensuring that people with disabilities have access to technologies that can help them use the web, and that web pages work with those technologies. (Hollier Scott, 2012). The "quantity" of information on a webpage is important but more important is it's "quality" and its "accessibility" which matters. Quality of webpage information can be rated under three headings firstly, the content based upon a need identification of the target audiences, the clarity with which the home page is displayed and thirdly how successfully can the target user reach/access the desired information. 


\section{INTERNATIONAL JOURNAL Of RESEARCH -GRANTHAALAYAH \\ A knowledge Repository}

Art

The STQC Directorate in India has been providing award to the organisations and institutions maintaining their websites with some accessible features that they have mentioned in their accessibility statement. The features incorporated in accessibility statement given by the directorate of STQC are based on internationally accepted standards such as ISO, and Web Content accessibility Guidelines (WCAG, 2008) of the World web Consortium (W3C), as adapted in the Indian Context. However a practice is found, very few professionals were already known the accessibility statement and not many WebPages including the STQC certified WebPages implemented the same. The aim of the study is to evaluate and analyse the Standard and accessibility of the international WebPages make use of the accessibility statements in their web design and to identify then most frequently to the least frequently used feature.

\section{CONCLUSION}

Accessibility statements which enable merging the digital divide are yet to be appreciated internationally. Accessibility on the webpages is still a low prior issue which is evident from the application of the survey shows that most of the international websites were not applied the accessibility features.

There is a need to apply accessibility features on the webpage to facilitate accessibility and the promote accessibility features on their webpage for universal accessibility without any barriers.

\section{ACKNOWLEDGEMENTS}

We acknowledge the support extended to us by Dr. Mathews Martin, Mass media officer AYJNIHH and Professor Rangasayee former Director of AYJNIHH and Information and media officer Shri. Rajesh.M for their support and inputs.

\section{REFERENCE}

[1] Accessibility, (2013).Wikipedia. Retrieved on July 15, 2013 from

(http://en.wikipedia.org/wiki/Accessibility Accessibility statement (2010)).

[2] STQC, Department of Electronics and information technology Retrieved on 2012, December

20, available in DEIT from, http://www.stqc.gov.in/content/learn-about-accessibility features

Census. (2011).

[3] Retrieved 2013, May 22 from, http://www.census India.gov.in/Ad campaign/press/data

Highlights.pdf

[4 ]Crystal. David English as a Global Language (2003): "A figure of 3\%, for example, is a

widely quoted estimate of the mid-1980s (e.g. Kachru (1986: 54))." from,

http://bolii.blogspot.in/2011/06/how-many-english-speakers-in-india.html

[5] Dan Camden., Sheryl., \& Burgstahler., university of Washington Internationally (2001),

from, http://www.washington.edu/doit/Brochures/Technology/universal.design.html 


\section{INTERNATIONAL JOURNAL Of RESEARCH -GRANTHAALAYAH \\ A knowledge Repository}

Art

[6] DiMaggio., Paul., EszterHargittai., Coral Celeste., \& Steven Shafer. 2004a. "Digital Inequality":

[7] From Unequal Access to Differentiated Use." Pp. 355-400 in Social Inequality, edited by Kathryn Neckerman.

[8] New York:Russell Sage Foundation._2004b. "Digital Inequality: From Unequal Access to Differentiated Use." in SocialInequality, edited by Kathryn Necker man. New York: Russell Sage Foundation

[9] Generation Y, 2013. Retrieved on 14 August 2013, from

http://www.generationy.com/definition/

[10] Hargittai, Eszter. (2003). "The Digital Divide and What to Do About It." Pp. 822-839 in Hollierscott, .Dr. (2012, November 6).

[11] Web accessibility: Supporting people with Disabilities. Retrieved from http://rightnow.org.au/topics/disability/web-accessibility-supporting-people-with-disabilities/ Karen Ngai, (2003-2004).

[12] The united nations and enabled persons Rehabilitation Alliance, Hong Kong (http://www.un.org/esa/socdev/enable/dis50y01.htm)

[13] Right to Information, (2005). Right to Information act of India, Retrieved on 16, August 2013 from, http://rti.gov.in/

Tim Berners-Lee, \&Jeffrey Jaffe, (2012) World Wide Web Consortium retrieved on July, 15(2013) (W3C) http://www.w3.org/Consortium/

[14] University of Washington, (2008). Universal Design and principles Retrieved on 16, August 2013. From, http://www.washington.edu/doit/Brochures/Programs/ud.html [15] Van Dijk. \& Jan A.G.M. 2005. The Deepening Divide. London: Sage Publications Vatican Holy See., Retrieved (2013, January 16) http://www.vatican.va/phome_en.htm Vatican publishing house.

[16] WCAG, (2008).Recommendation of sign language videos.Retrieved on June 5, 2013, from http://www.w3.org/TR/WCAG/ P. No (1.2.6).

[17] Web content accessibility guidelines, (2008). W3C Recommendation 11 December 2008. Retrieved on July 15, 2013 from http://www.w3.org/TR/WCAG/ [18] WHO, (2013).Classification of health.Retrieved on 1August, 2013. From http://www.who.int/classifications/icf/en/ WHO, (2001). [19] International classification of functioning, disability and health Page no.7.Published by world health organization. 


\section{INTERNATIONAL JOURNAL of RESEARCH -GRANTHAALAYAH \\ A knowledge Repository} Art

\section{APPENDIX A}

Sampled Webpages and reason for selection:

\begin{tabular}{|l|l|l|}
\hline $\begin{array}{r}\text { Sl } \\
\text { No. }\end{array}$ & $\begin{array}{l}\text { International } \\
\text { WebPages }\end{array}$ & Reason for selection \\
\hline 1 & $\begin{array}{l}\text { World Health } \\
\text { Organisation }\end{array}$ & $\begin{array}{l}\text { The World Health Organization (WHO) is a specialized agency of } \\
\text { the United Nations (UN) that is concerned with international public } \\
\text { health. }\end{array}$ \\
\hline 2 & $\begin{array}{l}\text { United nations } \\
\text { organisations }\end{array}$ & $\begin{array}{l}\text { an international organization whose stated aims include promoting } \\
\text { and facilitating cooperation in international law, international } \\
\text { security, economic development, social progress, human rights, civil } \\
\text { rights, civil liberties, political freedoms, democracy, and the } \\
\text { achievement of lasting world peace. }\end{array}$ \\
\hline 3 & $\begin{array}{l}\text { United nations } \\
\text { International } \\
\text { Children } \\
\text { educational } \\
\text { fund }\end{array}$ & $\begin{array}{l}\text { Provides long term humanitarian and developmental assistance } \\
\text { to children and mothers in developing countries. }\end{array}$ \\
\hline & $\begin{array}{l}\text { URL: http://en.wikipedia.org/wiki/United_Nations } \\
\text { URL: https://en.wikipedia.org/wiki/UNICEF }\end{array}$ \\
\hline
\end{tabular}




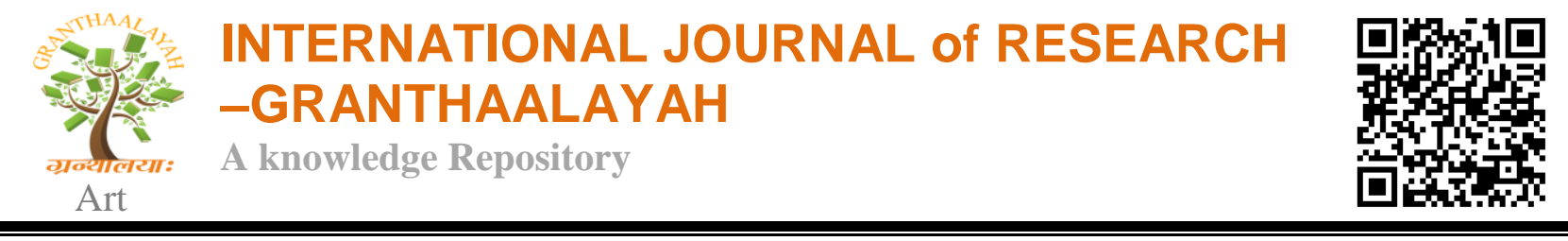

\begin{tabular}{|c|c|c|}
\hline 4 & $\begin{array}{l}\text { United nations } \\
\text { high } \\
\text { Commission } \\
\text { for Refugees }\end{array}$ & $\begin{array}{l}\text { United Nationsagency mandated to protect and support refugees at } \\
\text { the request of a government or the UN itself and assists in their } \\
\text { voluntary repatriation, local integration or resettlement to a third } \\
\text { country }\end{array}$ \\
\hline & \multicolumn{2}{|c|}{$\begin{array}{l}\text { URL: } \\
\text { http://en.wikipedia.org/wiki/United_Nations_High_Commissioner_for_Refugees }\end{array}$} \\
\hline 5 & $\begin{array}{l}\text { American } \\
\text { Speech and } \\
\text { Hearing } \\
\text { Association }\end{array}$ & 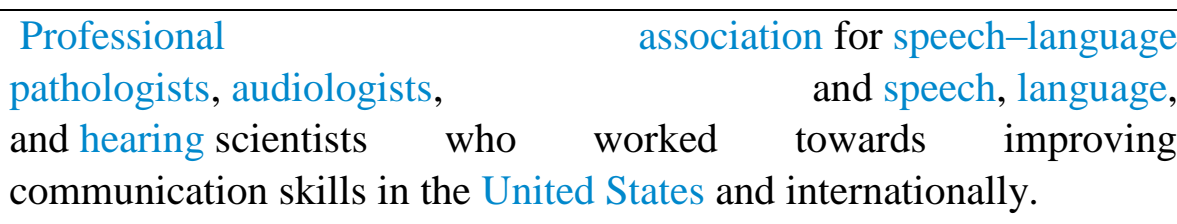 \\
\hline & \multicolumn{2}{|c|}{$\begin{array}{l}\text { URL:http://en.wikipedia.org/wiki/American_Speech\%E2\%80\%93Language\%E2\%80 } \\
\text { \%93Hearing_Association }\end{array}$} \\
\hline 6 & Google & $\begin{array}{l}\text { An American multinational corporation specializing in Internet- } \\
\text { related services and products. These include search, cloud } \\
\text { computing,software and online advertising technologies. Most of its } \\
\text { profits are derived from Advertisement Words }\end{array}$ \\
\hline & \multicolumn{2}{|c|}{ URL: http://en.wikipedia.org/wiki/Google } \\
\hline 7 & Yahoo & $\begin{array}{l}\text { It is one of the most popular sites in the United States. According to } \\
\text { news sources, roughly } 700 \text { million people visit Yahoo! websites } \\
\text { every month. Yahoo! itself claims it attracts "more than half a billion } \\
\text { consumers every month in more than } 30 \text { languages." }\end{array}$ \\
\hline & \multicolumn{2}{|c|}{ URL: http://en.wikipedia.org/wiki/Yahoo! } \\
\hline 8 & YouTube & $\begin{array}{l}\text { YouTube is a video-sharing website, which users can upload, view } \\
\text { and share videos. Of user-generated video content, including }\end{array}$ \\
\hline
\end{tabular}




\section{INTERNATIONAL JOURNAL Of RESEARCH -GRANTHAALAYAH \\ A knowledge Repository}

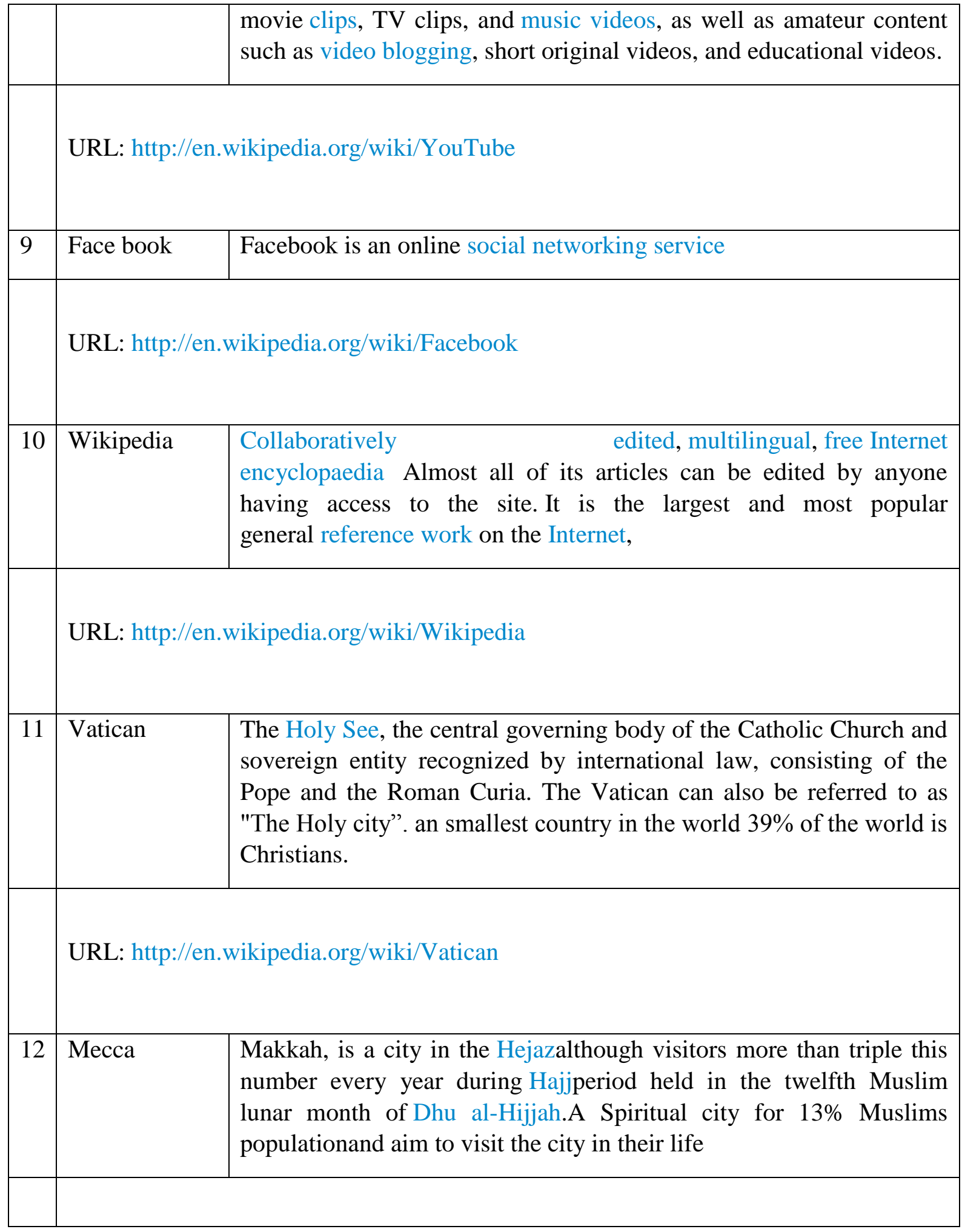




\section{INTERNATIONAL JOURNAL of RESEARCH -GRANTHAALAYAH \\ A knowledge Repository}

Art

\begin{tabular}{|c|c|c|}
\hline & \multicolumn{2}{|c|}{ URL: http://en.wikipedia.org/wiki/Mecca } \\
\hline 13 & World bank & $\begin{array}{l}\text { The World Bank is an international financial institution that } \\
\text { provides loans to developing countries for capital programs. } \\
\text { The World Bank's official goal is the reduction of poverty }\end{array}$ \\
\hline & \multicolumn{2}{|c|}{ URL: http://en.wikipedia.org/wiki/World_bank } \\
\hline 14 & $\begin{array}{l}\text { National } \\
\text { Institute for } \\
\text { person with } \\
\text { Multiple } \\
\text { Disabilities }\end{array}$ & $\begin{array}{l}\text { It is the latest National Institute for Empowerment of Persons with } \\
\text { Multiple Disabilities or NIEPMD is established by Government of } \\
\text { India under the aegis of Department of Disability Affairs, Ministry of } \\
\text { Social Justice \& Empowerment at Chennai for providing various } \\
\text { services to persons with multiple disabilities. }\end{array}$ \\
\hline & \multicolumn{2}{|c|}{ URL: http://en.wikipedia.org/wiki/NIEPMD } \\
\hline 15 & $\begin{array}{lr}\text { Ministry } & \text { of } \\
\text { Road and } \\
\text { Transport } \\
\text { India }\end{array}$ & $\begin{array}{l}\text { The Ministry of Road Transport and Highways, a branch of } \\
\text { the Government of India, is the apex body for formulation and } \\
\text { administration of the rules, regulations and laws relating to road } \\
\text { transport, national highways and transport research, in order to } \\
\text { increase the mobility and efficiency of the road transport system } \\
\text { in India. }\end{array}$ \\
\hline & $\begin{array}{l}\text { URL:http://en.w } \\
\text { a) }\end{array}$ & ikipedia.org/wiki/Ministry_of_Road_Transport_and_Highways_(Indi \\
\hline 16 & $\begin{array}{l}\text { Perkins Blind } \\
\text { school }\end{array}$ & $\begin{array}{l}\text { Perkins School for the Blind, in Watertown, Massachusetts, is the } \\
\text { oldest school for the blind in the United States }\end{array}$ \\
\hline
\end{tabular}




\section{INTERNATIONAL JOURNAL of RESEARCH -GRANTHAALAYAH \\ A knowledge Repository}

Art

\begin{tabular}{|c|c|c|}
\hline & URL: http://en. & vikipedia.org/wiki/Perkins_School_for_the_Blind \\
\hline 17 & $\begin{array}{l}\text { Gallaudet } \\
\text { University(AS } \\
\text { LP Studies) }\end{array}$ & $\begin{array}{l}\text { Gallaudet University is a federally chartered university for the } \\
\text { education of the deaf and It was the first school for the advanced } \\
\text { education of the deaf and hard of hearing in the world, and is still the } \\
\text { only higher education institution in which all programs and services } \\
\text { are specifically designed to accommodate deaf and hard of hearing } \\
\text { students. }\end{array}$ \\
\hline & URL:http://en.I & ikipedia.org/wiki/Gallaudet_University \\
\hline 18 & White House & $\begin{array}{l}\text { The White House is the official residence and principal workplace of } \\
\text { the President of the United States, }\end{array}$ \\
\hline & URL:http://en.I & ikipedia.org/wiki/White_house \\
\hline 19 & Qatar & Richest country of world \\
\hline & $\begin{array}{l}\text { URL:http://ww } \\
\text { 2013/ }\end{array}$ & v.clicktop10.com/2013/05/top-10-richest-countries-in-the-world-in- \\
\hline 20 & Canada & Highest educated population country \\
\hline & $\begin{array}{l}\text { URL:http://fina } \\
\text { world.html }\end{array}$ & ace.yahoo.com/news/the-10-most-educated-countries-in-the- \\
\hline 21 & Congo & $\begin{array}{l}\text { The Democratic Republic of the Congo has become the poorest } \\
\text { country in the world as of } 2010 \text {. }\end{array}$ \\
\hline
\end{tabular}




\section{INTERNATIONAL JOURNAL of RESEARCH -GRANTHAALAYAH \\ A knowledge Repository}

URL:http://www.therichest.com/world/poorest-countries-in-the-world/

\begin{tabular}{|l|l|l|}
\hline 22 & Niger & Highest Adult illiteracy rate84.3\% \\
\hline & $\begin{array}{l}\text { URL:http://www.whichcountry.co/top-10-countries-with-highest-illiteracy-rate-in-the- } \\
\text { world/ }\end{array}$ \\
\hline 23 & Burkino.Faso & World unhealthiest country \\
\hline
\end{tabular}

URL:http://www.news.com.au/lifestyle/health-fitness/revealed-the-top-ten-healthiestand-unhealthiest-countries/story-fneuz9ev-1226536906813

\begin{tabular}{|c|c|c|}
\hline 24 & $\begin{array}{l}\text { Massachusetts } \\
\text { University }\end{array}$ & No1 university in the world \\
\hline & \multicolumn{2}{|c|}{$\begin{array}{l}\text { URL:http://www.usnews.com/education/worlds-best-universities-rankings/top-400- } \\
\text { universities-in-the-world }\end{array}$} \\
\hline 25 & $\begin{array}{l}\text { American } \\
\text { Embassy } \\
\text { school }\end{array}$ & No.1 school in the world located at New Delhi \\
\hline & \multicolumn{2}{|c|}{ URL:http://www.insignia-lb.com/2008/05/20/schools/ } \\
\hline 26 & US Army & Most Powerful army in the world \\
\hline & \multicolumn{2}{|c|}{$\begin{array}{l}\text { URL:http://www.businessinsider.com/10-most-powerful-militaries-in-the-world-2013- } \\
6 ? \mathrm{op}=1\end{array}$} \\
\hline
\end{tabular}




\section{INTERNATIONAL JOURNAL Of RESEARCH -GRANTHAALAYAH \\ A knowledge Repository}

\begin{tabular}{|c|c|c|}
\hline 27 & $\begin{array}{l}\text { Government } \\
\text { of China }\end{array}$ & Highest populated country \\
\hline & \multicolumn{2}{|c|}{ URL: http://en.wikipedia.org/wiki/List_of_countries_by_population } \\
\hline 28 & $\begin{array}{l}\text { Government } \\
\text { of Russia }\end{array}$ & Largest country in the world land.(Area) \\
\hline & \multicolumn{2}{|c|}{$\begin{array}{l}\text { URL:http://www.mapsofworld.com/world-top-ten/world-top-ten-largest-countries-in- } \\
\text { area-map.html }\end{array}$} \\
\hline 29 & $\begin{array}{l}\text { Royal } \\
\text { Canadian } \\
\text { police }\end{array}$ & No 1 Intelligence police forces in the world \\
\hline & \multicolumn{2}{|c|}{ Ref:http://www.listoffive.com/five-best-police-forces-in-the-world/ } \\
\hline 30 & Iceland & Most Peaceful country in the world \\
\hline & \multicolumn{2}{|l|}{ Ref: } \\
\hline & \multicolumn{2}{|c|}{ http://www.gfmag.com/tools/global-database/ne-data/11941-most-peaceful-countries.h } \\
\hline 31 & ITCU & E accessibility toolkit policy for pwds \\
\hline & \multicolumn{2}{|c|}{ URL: http://www.e-accessibilitytoolkit.org/ } \\
\hline
\end{tabular}




\section{INTERNATIONAL JOURNAL Of RESEARCH -GRANTHAALAYAH \\ A knowledge Repository} Art

\section{APPENDIX B}

The checklist to evaluate web pages in terms of accessibility

\begin{tabular}{|l|l|c|l|}
\hline $\begin{array}{l}\text { Sl. } \\
\text { No }\end{array}$ & Accessibility Statement/ Features & $\begin{array}{l}\text { Prescribed } \\
\text { by }\end{array}$ & $\begin{array}{l}\text { Present (1)/ } \\
\text { Absent (0) }\end{array}$ \\
\hline 1 & Skip to main content & STQC & \\
\hline 2 & Icons & STQC & \\
\hline 3 & Percentage of icons presented in webpage & STQC & \\
\hline 4 & Accessibility options & STQC & \\
\hline 5 & Size of the text & STQC & \\
\hline 6 & colour scheme & STQC & \\
\hline 7 & Increase The text Space & STQC & \\
\hline 8 & Identification of file type \&size & STQC & \\
\hline 9 & Icons for Different Types of Files & STQC & \\
\hline 10 & Main Headings & STQC & \\
\hline 11 & Sub Headings & STQC & \\
\hline 12 & Titles & STQC & \\
\hline 13 & Alternate text & STQC & \\
\hline 14 & Availability of tool tip (Mouse) & STQC & \\
\hline 15 & Consistent navigation mechanism & STQC & \\
\hline 16 & Keyboard support (Shift+ Tab) & STQC & \\
\hline 17 & Adjust contrast scheme & \\
\hline 18 & Contents in Indian language & & \\
\hline
\end{tabular}




\section{INTERNATIONAL JOURNAL of RESEARCH -GRANTHAALAYAH \\ A knowledge Repository} Art

\begin{tabular}{|c|l|c|c|}
\hline 19 & Screen saver option & WCAG & \\
\hline 20 & Access of screen Reader & WCAG & \\
\hline 21 & Visual Screening(any Videos) & WCAG & \\
\hline 22 & Availability of connections with social Networks & WCAG & \\
\hline \multicolumn{2}{|l|}{ TOTAL } & & \\
\hline
\end{tabular}




\section{INTERNATIONAL JOURNAL Of RESEARCH -GRANTHAALAYAH
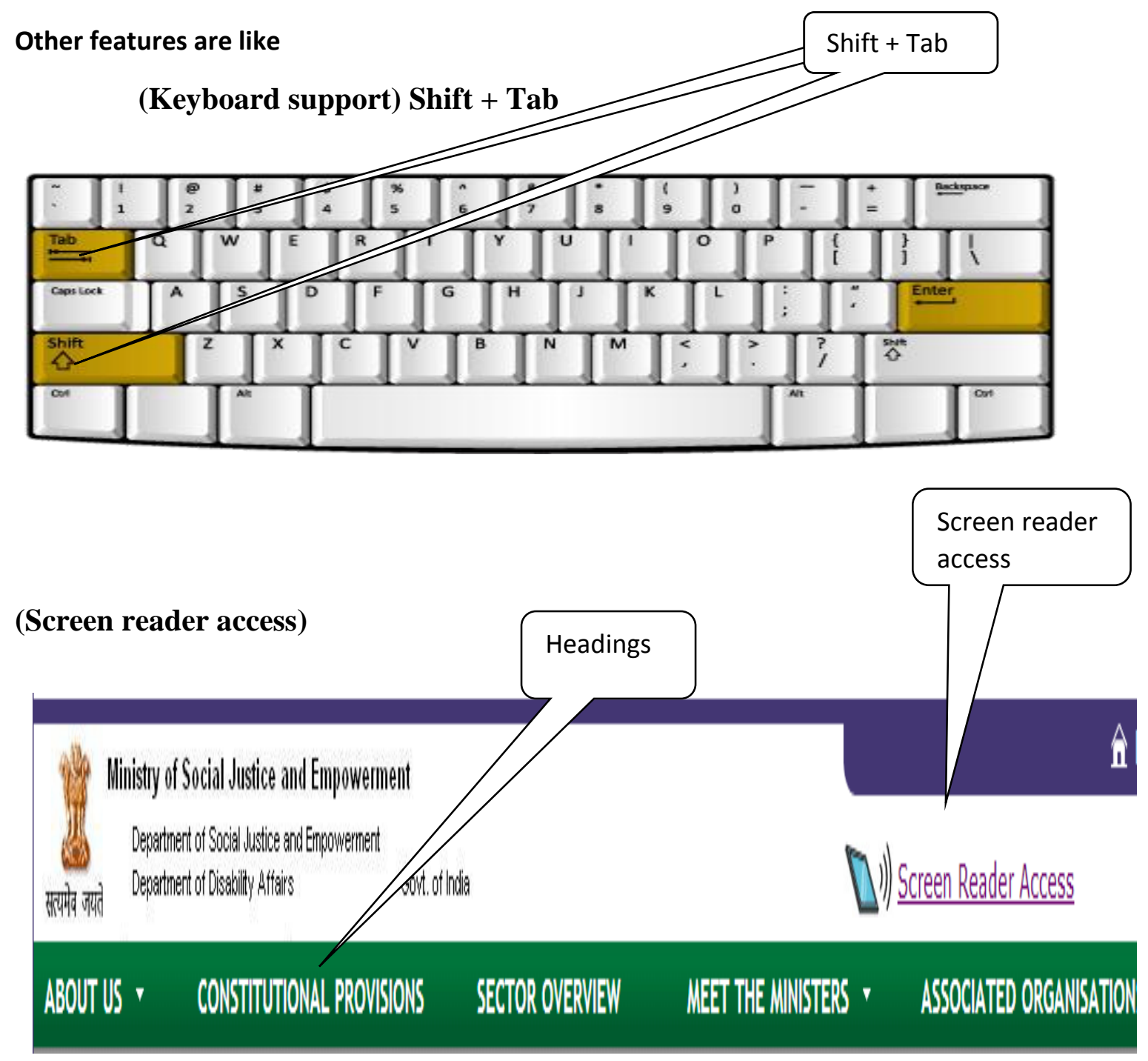


\section{(Videos- visual presentation)}

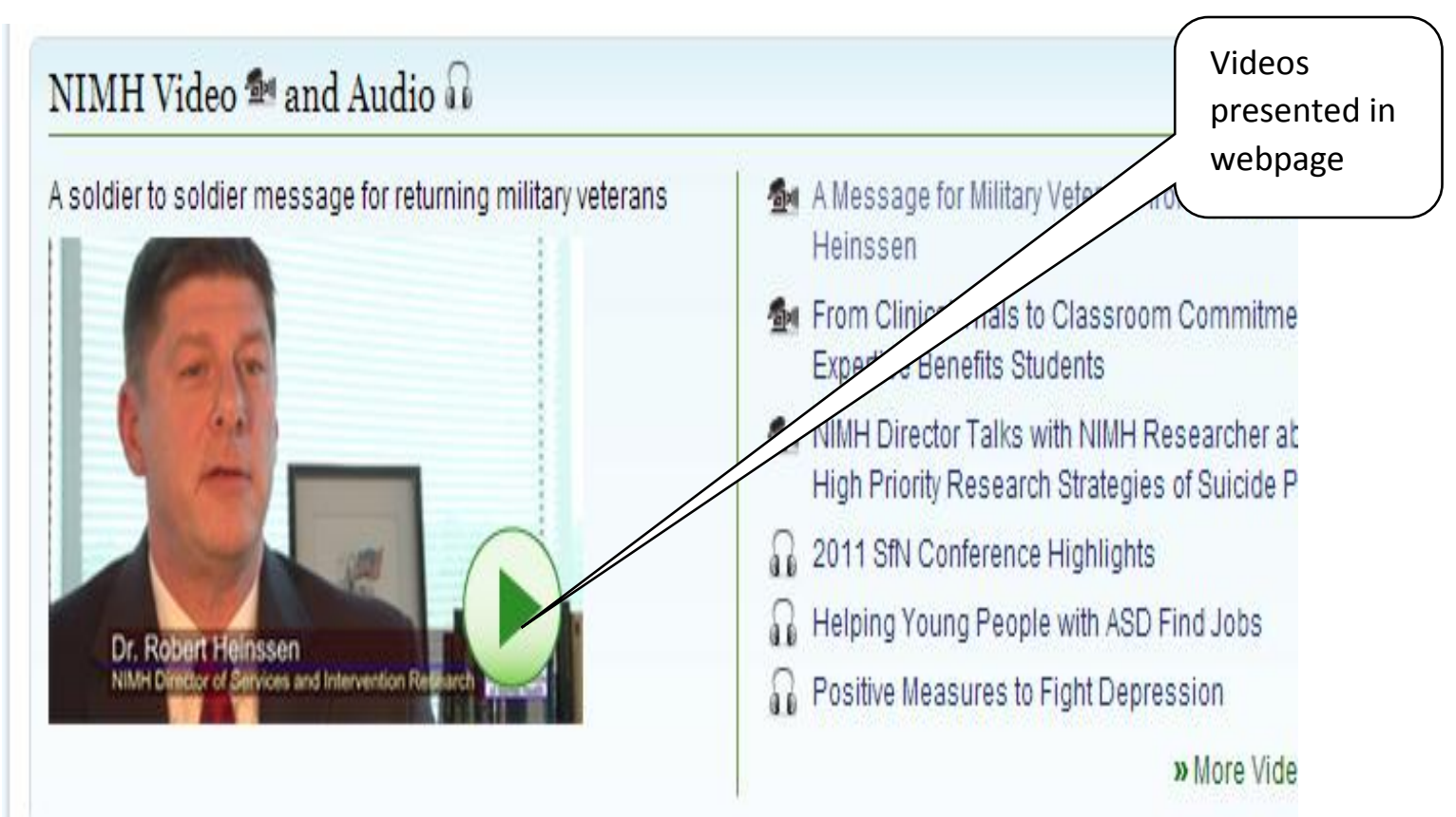

